\title{
Peran Keluarga pada Ibu Pasca Bersalin
}

\author{
Popy Apriyanti ${ }^{1}$, Atik Triratnawati ${ }^{2}$, Dhesi Ari Astuti ${ }^{3}$ \\ ${ }^{1}$ Mahasiwa S2 Kebidanan Universitas Aisyiyah, Yogyakrta, Indonesia \\ ${ }^{2}$ Departemen Antropologi FIB, Universitas Gadjah Mada, Yogyakarta, Indonesia \\ ${ }^{3}$ Universitas Aisyiyah, Yogyakarta, Indonesia \\ Korespondensi: popy.apriyanti@gmail.com
}

Submisi: 22 Juli 2020; Revisi: 27 Maret 2021; Penerimaan: 29 Maret 2021

\begin{abstract}
Background: The minimaze role of the family is someone who motivates, cares, encourages postpartum and is always with him and helps in dealing with changes due to childbirth so as to improve the welfare of life for the individual concerned.

Objective: This research aims to determine the role of the family starting from emotional support, information, instrumentals and appreciation for postpartum mothers.

Method: Qualitative study with a phenomenological approach using iln-depth interviews among 10 informants. Analysis of the data in this study used a combination of manual and nvivo programs.

Results and Discussion: The role of the family in postpartum mothers was conveyed when emotional support, information, instrumentals and rewards were optimal. The obstacles experienced by informants were time constraints due to work and the role of the husband which was more dominated by biological mothers / in-laws because they still lived in one house.

Conclusion: The role of family in post-partum mothers has a positive impact on the mental health of post-partum mothers.
\end{abstract}

Keywords: Family Role; Postpartum Mothers; Postpartum Midwifery Care

\section{ABSTRAK}

Latar Belakang: Minimnya peran keluarga merupakan orang yang memotivasi, perhatian, membesarkan hati dan orang yang selalu bersamanya serta membantu dalam menghadapi perubahan akibat adanya persalinan sehingga bisa meningkatkan kesejahteraan hidup bagi individu yang bersangkutan. Tujuan: Penelitian ini bertujuan untuk mengetahui peran keluarga mulai dari dukungan emosional, informasi, instrumental dan penghargaan pada ibu pasca bersalin.

Metode: Studi kualitatif dengan pendekatan fenomenologi menggunakan wawancara mendalam terhadap 10 informan. Analisis data dalam penelitian ini menggunakan kombinasi manual dan program nvivo.

Hasil dan Pembahasan: Peran keluarga pada ibu pasca bersalin disampaikan melalui dukungan emosional, informasi, instrumental dan penghargaan sudah optimal. Hambatan keterbatasan waktu karena bekerja, peran suami lebih didominasi oleh ibu kandung/mertua karena masih tinggal satu rumah.

Kesimpulan: Peran kelurga pada ibu pasca bersalin memiliki dampak positif untuk kesehatan mental ibu pasca bersalin.

Kata Kunci: Peran Keluarga; Ibu Pasca Bersalin; Asuhan Kebidanan Masa Nifas 


\section{PENDAHULUAN}

Ada beragam gangguan pada ibu pasca bersalin. Ibu mengalami gangguan pasca bersalin sekitar 25$85 \%$ ibu postpartum mengalami postpartum blues kemudian $10-20 \%$ mengalami depresi postpartum dan $5 \%$ menjadi psikosis. ${ }^{1}$ Diperkirakan wanita melahirkan dan mengalami postpartum blues sekitar 10 per 1000 kelahiran hidup, dan depresi postpartum 30-200 per 1000 kelahiran hidup.

Di Indonesia telah dilakukan beberapa penelitian gangguan postpartum seperti depresi postpartum (DPP). RS Hasan Sadikin Bandung mencatat kejadian DPP 33\%. Di RSUP Cipto Mangunkusumo Jakarta angka DPP sebesar 33\%, Di RSUD Serang angka DPP sekitar $30 \% .^{2}$

Pemerintah telah mendukung dan mengatur berbagai upaya untuk mendukung kesejahteraan ibu, bayi dan keluarga. Ini tertera dalam Peraturan Menteri Kesehatan Republik Indonesia no 28 tahun 2017 pasal 18 tentang penyelenggaraan praktik bidan yaitu bidan memiliki kewenangan dalam memberikan pelayanan kesehatan kepada ibu (masa kehamilan, persalinan dan nifas). Dalam Peraturan Pemerintah (PP) no 61 tahun 2014 mengenai kesehatan masa sesudah melahirkan meliputi pelayanan nifas. Pelayanan nifas yang dimaksud pada ayat (1) diberikan berupa promosi kesehatan, deteksi dini, gangguan kesehatan fisik dan mental serta pencegahan dan penanganan oleh tenaga kesehatan sesuai dengan pemberian pendidikan kesehatan kepada ibu dan keluarga. ${ }^{3}$ Tujuan penelitian ini untuk mengetahui peran keluarga pada ibu pasca bersalin.

\section{METODE}

Penelitian kualitatif dengan desain fenomenologi yang dilakukan tahun 2019/2020. Populasi penelitian adalah 5 ibu bersalin di RS SDW di Sleman, DIY yang dipilih dengan kriteria tertentu yang sesuai dengan tujuan penelitian. Selain itu ada 5 informan tambahan yaitu orang dewasa yang tinggal satu rumah dengan ibu bersalin (suami, mertua). Adapun teknik pengambilan sampel yang digunakan adalah purposive sampling dengan strategi criterian sampling. Adapun kriteria inklusi penelitian ini adalah Ibu postpartum primipara, suami yang tinggal satu rumah dengan istri, orang tua/ mertua perempuan yang tinggal serumah dengan informan pada saat ibu pasca bersalin. Analisis data menggunakan bantuan Computer Assisted Qualitative Data Analysis Software (CAQDAS) yaitu software Nvivo 11.4

\section{HASIL DAN PEMBAHASAN}

Aspek dukungan yang pertama dikaji oleh peneliti adalah dukungan emosional. Yang dimaksud dengan dukungan emosional adalah segala bentuk ekspresi kepedulian, perhatian dan empati yang diperoleh dari keluarga. Keluarga merupakan tempat yang aman dan damai untuk istirahat dan pemulihan serta membantu penguasaan terhadap emosi. Aspek-aspek dari dukungan emosional meliputi dukungan yang diwujudkan dalam bentuk afeksi, adanya kepercayaan, perhatian, mendengarkan dan didengarkan. ${ }^{5}$

Berdasarkan hasil temuan data dengan informan mengenai aspek dukungan emosional ditemukan bahwa mayoritas informan merasakan kebahagiaan atas kelahiran bayinya serta ibu bayi diberi karunia kesehatan.

Sebagaimana cuplikan wawancara peneliti dengan informan sebagai berikut:

"....Perasaan saya bahagia mbak karena dapat momongan, serta istri dan anak saya sehat" (Is.2).

Hal ini sejalan dengan penelitian Saroson bahwa dukungan suami yaitu keberadaan, kesediaan dan kepedulian dari orang-orang yang dapat diandalkan, menghargai serta menyayangi dalam hal ini adalah suami memberikan dukungan pada ibu sehingga menciptakan suasana kebahagian atas kelahiran bayi. $^{6}$

Subtema ideal pada penelitian ini bahwa semua informan memiliki dukungan emosional yang baik dari suami seperti kepedulian suami, perhatian, semangat dan perhatian khusus yang diberikan seperti menyediakan waktu untuk ibu dan bayinya. Sebagaimana cuplikan wawancara peneliti dengan informan sebagai berikut: 
"...Ya lebih diperhatikan aja mbak apalagi pada masa pemulihan"(Is.5).

"....Ya jangan dikasih banyak pikiran dulu, biar gak ngaruh ke ASI ibunya"(Ik.4).

Hal ini sesuai dengan penelitian pada masa postpartum bahwa penting adanya kehadiran, perhatian dan keterlibatan suami untuk menghindari gangguan pada kesehatan emosional ibu seperti depresi postpartum sehingga dapat membantu kembali ke kehidupan yang normal. ${ }^{7}$

Temuan pada aspek dukungan emosional secara keseluruhan sangat baik karena menunjukkan keterlibatan suami yang besar selama ibu pasca bersalin.

Hal ini terlihat dari bentuk dukungan sampai manfaat dukungan. Ini artinya suami memahami bahwa selama ibu pasca bersalin aspek-aspek dari dukungan emosional meliputi dukungan yang diwujudkan dalam bentuk afeksi, adanya kepercayaan, perhatian, mendengarkan dan didengarkan sangat dibutuhkan untuk pemulihan ibu pasca bersalin. ${ }^{8}$

Aspek kedua yang digunakan dalam penelitian ini adalah dukungan informasi. Jenis dukungan ini meliputi jaringan komunikasi dan tanggung jawab bersama, termasuk didalamnya memberikan solusi atas masalah, memberikan nasihat, pengarahan, saran atau umpan balik tentang apa yang dilakukan oleh seseorang. ${ }^{9}$ Hasil temuan data pada dukungan informasi menunjukkan munculnya tema yaitu bentuk dukungan informasi, sumber dukungan dan manfaat dukungan.

Dalam hal ini bentuk dukungan informasi mencakup subtema terkait pemilihan rumah sakit dan perawatan masa nifas. Keterlibatan seorang suami dalam perawatan kesehatan ibu merupakan proses perubahan sosial, sehingga suami lebih bertanggung jawab dalam kesehatan ibu dengan tujuan menjamin ibu dan anak dengan kondisi baik.

Sebagaimana cuplikan wawancara peneliti dengan informan sebagai berikut:

"....Kalau informasi itu ya bermacam-macam mulai dari milih rumah sakit. Terus informasi kayak biar cepet lahirannya diapain...terus habis lahiran ya dikasih tahu harus minum jamu. Dikasih tahu saya disuruh ngapain aja, setelah istri melahirkan misalkan diminta ikut bantu momong biar istri ndak gampang capek. Dari bidan ada kayak makan dan minum bergizi supaya susunya untuk anak nanti mengandung makanan" (Is.1).

Hal ini sejalan dengan keterangan yang diungkapkan informan, dalam hal informasi mengenai pertimbangan rumah sakit mencakup mengenai pertimbangan dokter dan bidan. ${ }^{10}$

Temuan lain menunjukkan subtema perawatan masa nifas bahwa mayoritas informan menunjukkan adanya bentuk dukungan informasi seperti perawatan masa nifas. Menurut informan, informasi perawatan masa nifas diantaranya meliputi pentingnya membersihkan luka, ASI, perawatan bayi, nutrisi yang seimbang, kemudian puasa/ berpantang berhubungan seksual. ${ }^{11}$

Dalam tema sumber dukungan instrumental mencakup subtema suami, orangtua, saudara, rekan kerja. Hasil temuan didapatkan bahwa orang tua ibu pasca bersalin yaitu mertua lebih banyak memberikan bantuan berupa non material sedangkan suami bantuan non material lebih sedikit tetapi optimal dalam memberikan dukungan material.

Faktor sosial budaya juga mempunyai peranan penting dalam memahami sikap dan perilaku keluarga dalam menangani perawatan ibu dan bayi pasca bersalin. Dari kajian antropologi, ditemukan bahwa masalah terkait perawatan ibu dan bayi tidak selalu ditentukan oleh pasangan suami istri. Melainkan oleh anggota kerabat lain yang lebih senior dan berpengalaman dalam merawat bayi. ${ }^{12}$ Hal ini seperti tercatum pada cuplikan wawancara berikut ini:

"....Ketika anak saya lahir saya kontak ibu dibuatkan brokohan dibagikan ke tetangga, sama pas udah hari kelima kita melaksanakan sepasaran ngundang orang ke rumah"(Is.2).

"...lbu saya yang paling banyak memberikan dukungan dan memperhatikan, membuatkan acara penyambutan bayi" (li.1). 
Hasil analisis lanjutan menunjukkan bahwa bentuk dukungan mencakup subtema berupa bantuan dalam mengerjakan pekerjaan domestik dan perawatan bayi. Secara keseluruhan suami tidak optimal dalam membantu pekerjaan domestik, tetapi sebaliknya suami terlibat perannya sebagai penyedia keuangan (dana), mendukung dan menyediakan serta menyiapkan makanan.

Suami juga bertugas untuk mencari bantuan apabila istri ada masalah terkait kesehatan. ${ }^{13}$ Penelitian Lewis juga menunjukkan bahwa keterlibatan suami sebatas pada bantuan keuangan untuk mengatasi masalah kesehatan reproduksi. ${ }^{14}$

Aspek lain yang terlihat dari penelitian ini adalah dukungan penghargaan. Dukungan ini juga merupakan dukungan yang bersifat ekspresif yang berakibat penilaian yang positif terhadap individu. Orang Jawa dalam merawat dan mengasuh anak setelah melahirkan tidak dapat dilepaskan dari upacara tradisi. Upacara tradisi itu antara lain brokohan, sepasaran, puput puser dan selapanan, yang melambangkan harapan-harapan bagi si bayi pada kehidupan kelak. ${ }^{15}$ Hal ini sejalan dengan penemuan peneliti bahwa mayoritas informan melakukan penyambutan bayi yang disertai dengan upacara brokohan, jenengan, sepasaran maupun aqiqoh. Acara ini dilaksanakan dalam rangka menyambut sang bayi dengan cara membagikan makanan ke tetangga berupa makanan yang sudah dimasak yang terdiri dari nasi dan lauk sayur. Pada upacara jenengan mereka mengundang tetangga sekitar atau kerabat sehingga pemberian nama buah hati mereka diumumkan. ${ }^{16}$

\section{KETERBATASAN PENELITIAN}

Penelitian ini memiliki keterbatasan baik dalam proses pengumpulan data, analisis maupun interpretasi data. Hal ini dikarenakan peneliti merupakan peneliti pemula khususnya dengan menggunakan metode kualitatif. Wawancara mendalam yang dilakukan terbatas oleh waktu waktu dan terganggu oleh keadaan sekitar. Pada saat proses analisis data peneliti menemukan adanya kesulitan dalam menetapkan tema. Tetapi hal ini dapat diatasi dengan konsultasi pada para ahli.
Banyak pengalaman baru ditemukan saat berinteraksi dan menggali kisah hidup masingmasing informan. Akan tetapi peneliti mengalami kesulitan dalam menarasikan data yang ada. Namun, dari pengalaman tersebut ada banyak informasi penting guna memahami peran keluarga pada ibu pasca bersalin terkait dukungan emosional, instrumental, informasi, penilaian, serta faktor yang mempengaruhi dan menghambat peran keluarga pada ibu pasca bersalin.

\section{IMPLIKASI KEBIDANAN}

Penelitian ini menghasilkan beberapa keterkaitan antara bentuk-bentuk dukungan mulai dari dukungan emosional, instrumental, informasi, penilaian dan faktor-faktor yang mempengaruhi/menghambat peran keluarga pada ibu pasca bersalin. Bidan dalam melakukan asuhan masa nifas dapat mengantisipasi dengan meringankan atau mengurangi gangguan psikologis pada ibu melalui peran keluarga pada ibu pasca bersalin. Salah satu hal yang dapat dilakukan untuk mengurangi aspek psikis yang negatif pada ibu adalah adanya perhatian keluarga. Peran keluarga ini akan membangun kestabilan emosi ibu.

Penelitian ini mencoba mengembangkan teori pengukuran peran keluarga dilihat dari empat komponen yaitu dukungan emosional, instrumental, informasi, dan penilaian bisa diterapkan sebagai salah satu Health Technologhy Assessment (HTA) guna mengoptimalkan peran keluarga pada ibu pasca bersalin.

Temuan penelitian ini juga dapat menjadi dasar bagi bidan guna mengembangkan peran mereka sebagai advocator dan educator. Antara lain dengan cara menjelaskan kepada suami akan pentingnya dukungan terhadap istri pasca bersalin. Peran bidan adalah penghubung, lewat cara mengkomunikasikan kepada tokoh masyarakat dan perangkat desa terkait dengan masalah yang dialami oleh ibu paska bersalin. Di budaya setempat, yaitu budaya Jawa masih ada pemahaman bahwa membantu istri dalam pekerjaan rumah tangga/domestik dianggap tabu dilakukan oleh suami. Kondisi ini mengakibatkan adanya hambatan sosial budaya dalam memberikan dukungan pada ibu pasca bersalin karena hal itu belum sepenuhnya terwujud. 


\section{KESIMPULAN DAN SARAN}

Peran keluarga pada ibu pasca bersalin sudah terlaksana secara optimal di setiap bentuk-bentuk dukungan. Pengaruh budaya Jawa menjadi hambatan dalam memberikan dukungan instrumental yakni adanya budaya tabu melakukan pekerjaan rumah tangga bagi para suami. Inovasi untuk mengoptimalkan peran keluarga misalnya membuat kelas ayah serta peran bidan sebagai advocator dan educator kepada tokoh masyarakat dan perangkat desa terkait dengan masalah yang dialami oleh ibu pasca bersalin. Hal ini penting dilakukan mengingat peran keluarga memiliki dampak positif untuk kesehatan mental mereka

\section{DAFTAR PUSTAKA}

1. World Health Organization. (2015). WHO Recommendations On Health Promotion Interventions For Maternal And Newborn Health. Geneva: WHO.p. 1-94.

2. Soep. (2011). Penerapan Edinburgh Postpartum Depression Scale Alat Deteksi Resiko Depresi Nifas Pada Primipara Dan Multipara. Jurnal Keperawatan Indonesia. 14(2): pp. 95-100.

3. Peraturan Menteri Kesehatan RI Nomor 61. (2014). Pelayanan Kesehatan Masa Sebelum Hamil, Masa Hamil, Persalinan, Dan Masa Sesudah Melahirkan, Penyelenggraan Pelayanan Kontrasepsi, Serta Pelayanan Kesehatan Seksual.

4. Afriyanti, Y, dan Rachmawati, I. (2014). Metodologi Penelitian Kualitatif dalam Riset Keperawatan. Jakarta: PT Raja Grafindo Persada.

5. Alio, A. P., Lewis C.A., Scarborough, K., Harris, K., dan Fiscella, K. (2013). A Community Perspective On The Role Of Fathers During Pregnency: A Qualitative Study. BMC Pregnency and Childbirth. 13(1): 60. Doi: 10.1186/1471-2393-13-60.

6. Saroson, I.G. (2012). Assessing Social Support: The Social Support Questionnaire. Journal of Personality and Social Psychology. 44: 17-139.

7. Firouzan, V., Noroozi, M., Farajzadegan, Z., Mirghafourvand, M. (2019). Barriers to men's participation in perinatal care: a qualitative study in Iran. BMC Pregnancy and Childbirth 19. https://doi.org/10.1186/s12884-0192201-2
8. Respati, S.H., Sulistyowati, S. dan Nababan, R., (2019). Analisis Faktor Determinan Kematian Ibu di Kabupaten Sukoharjo Jawa Tengah Indonesia. Jurnal Kesehatan Reproduksi. 6(2): pp.52-59.

9. Firouzan, V., Noroozi, M., Mirghafourvand, M., Farajzadegan, Z., (2018). Participation of father in perinatal care: a qualitative study from the perspective of mothers, fathers, caregivers, managers and policymakers in Iran. BMC Pregnancy and Childbirth 18. https://doi. org/10.1186/s12884-018-1928-5

10. Sarafino, E, P. (2011). Health Psychology Biopsychososial Interaction. Second Edition. New York: John Wiley and Sons.

11. Kululanga, L.I., Sundby, J., Malata, A., (2012). Chirwa, E. Male Involvement in Maternity Health Care in Malawi. African Journal of Reproductive Health. 16(1): 145.

12. Sennen H, William W, Aluisio J. D. Barros. (2015) Patterns And Trends Of Postpartum Family Planning In Ethiopia, Malawi, And Nigeria: Evidence Of Missed Opportunities For Integration, Global Health Action. 8: 1. 29738, DOI: 10.3402/gha.v8.29738

13. Kabagenyi, A., Jennings, L., Reid, A., Nalwadda, G., Ntozi, J., Atuyambe, L., (2014). Barriers To Male Involvement In Contraceptive Uptake And Reproductive Health Services: A Qualitative Study Of Men And Women's Perceptions In Two Rural Districts In Uganda. Reprod Health 11. https://doi.org/10.1186/1742-4755-11-21.

14. Lewis, S., Lee, A., Simkhada, P., (2015). The Role Of Husbands In Maternal Health And Safe Childbirth In Rural Nepal: A Qualitative Study. BMC Pregnancy and Childbirth. https://doi. org/10.1186/s12884-015-0599-8

15. Mumpangati, T. (2016). Potret Pengasuhan Anak Sejak Dalam Kandungan Hingga Remaja Pada Masyarakat Jawa. Yogyakarta: Badan Pelestarian Nilai Budaya.

16. Webster, J., Nicholas, C., Velacott, C., Cridland, N., dan Fawcett, L. (2011). Quality of Life and Depression Following Childbirth: Impact of Sosial Support. Midwifery. 27(5): 745-9. 